\title{
STUDI LITERATUR: ANALISIS TEORI BISNIS DALAM AKTIVITAS KEWIRAUSAHAAN
}

\author{
Nur Wahyuning Sulistyowati \\ IKIP PGRI MADIUN \\ laurafredikson@yahoo.co.id
}

\begin{abstract}
ABSTRAK
Penelitian ini merupakan studi literatur yang membahas Teori Bisnis Dalam Aktivitas Kewirausahaan. Pada studi literatur penelitian ini, terdapat kegunaan teori dalam aktivitas kewirausahaan. Bisnis dalam studi ini memfokuskan pada kelayakan usaha dan pertumbuhan usaha dalam aktivitas kewirausahaan. Hasil studi menunjukkan bahwa pentingnya kegunaan teori bisnis dalam kelayakan usaha dan pertumbuhan usaha. Penelitian berikutnya yang menarik untuk dikembangkan sebagai riset adalah Analisis Teori Bisnis Sumber Daya Manusia dalam Aktivitas Kewirausahaan.
\end{abstract}

Kata kunci: Studi Literatur, Teri Bisnis, Aktivitas Kewirausahaan.

\section{PENDAHULUAN}

Pengusaha adalah faktor yang paling menentukan dalam pertumbuhan ekonomi suatu negara yang mampu melakukan inovasi dan kreatifitas, dan agar suatu negara menjadi makmur diperlukan sedikitnya $2 \%$ dari penduduknya yang menjadi pengusaha (Wibowo: 2011). Adanya pertumubuhan wirausaha akan membawa peningkatan perekonomian yang luar biasa bagi suatu negara, sehingga semakin banyak suatu negara memiliki wirausaha, maka akan semakin meningkat perekonomiannya (Nurul, I. N: 2015).

Usaha menumbuhkan wirausaha diikuti dengan kegunaan teori bisnis dalam kelayakan usaha dan pertumbuhan usaha. Sehingga dalam aktivitas kewirausahaan diperlukan teori bisnis yang diharapkan mampu menumbuhkan usaha dan kelayakan usaha.

Manajemen Sumber Daya Manusia adalah fungsi dalam sebuah organisasi yang berfokus pada perekrutan, pengelolaan, dan memberikan arahan untuk orang-orang yang bekerja dalam organisasi. Orang yang bekerja untuk sebuah perusahaan adalah salah satu aset utama dan salah satu faktor dalam menentukan kemajuannya. Kualitas pekerja, sikap dan perilaku di tempat kerja, bersama dengan faktor lain, memainkan peran penting dalam menentukan keberhasilan perusahaan Hashemi, K (2012). Hubungan yang signifikan antara fungsi sumber daya manusia, pengelolaan sumber daya dan kewirausahaan. Sumber daya manusia dalam organisasi adalah prinsip utama dari organisasi dan keberadaan lingkungan kompetitif, dioptimalkan menggunakan kekuatan mental dan eksekutif karyawan untuk memperkuat inovasi dan kreativitas Hassanpour, A., et al (2012).

Pada literatur review ini, penelitian memfokuskan pada Analisis Teori Bisnis dalam Aktivitas Kewirausahaan. Dari kedua teori telah menunjukkan bahwa sumber daya manusia berperan sangat penting dalam aktivitas kewirausahaan. Dimana selain sumber daya manuisa, perspektif keuangan dan organisasi, serta etika bisnis masih berkaitan erat dengan aktivitas kewirausahaan, sehingga pada literatur ini diperlukan tinjauan literatur lebih lanjut. 


\section{KAJIAN PUSTAKA}

Kewirausahaan (entrepreneurhip) merupakan persoalan penting di dalam perekonomian suatu bangsa yang sedang berkembang. Kemajuan atau kemunduran ekonomi suatu bangsa sangat ditentukan oleh keberadaan dan peranan dari kelompok wirausahawan ini (Rachbini: 2002). Peter Drucker (1993) menyatakan bahwa seluruh proses perubahan ekonomi pada akhirnya tergantung dari orang yang menyebabkan timbulnya perubahan tersebut yakni sang "entrepreneur". Kebanyakan perusahaan yang sedang tumbuh dan yang bersifat inovatif menunjukan suatu jiwa (spirit) entrepreneur. Korporasi-korporasi berupaya untuk mendorong para manajer mereka menjadi orang-orang yang berjiwa entrepreneur, universitas-universitas sedang mengembangkan program-program entrepreneurhip, dan para entrepreneur individual menimbulkan perubahan-perubahan dramatik dalam masyarakat. Keberhasilan pembangunan yang dicapai oleh negara Jepang ternyata disponsori oleh para entrepreneur yang berjumlah $2 \%$ tingkat sedang, berwirausaha kecil sebanyak $20 \%$ dari jumlah penduduknya. Inilah kunci keberhasilan pembangunan negara Jepang (Heidjrachman Ranu, 1982). Jumlah entrepreneur di Indonesia masih sedikit dan mutunya belum bisa dikatakan hebat untuk menopang perekonomian, sehingga persoalan wirausaha ini menjadi persoalan yang mendesak bagi suksesnya pembangunan perekonomian di Indonesia.

\section{Perspektif keuangan dan organisasi pada kelompok usaha kecil menengah}

Minat belajar kelompok usaha baru-baru ini berkembang, sebagai akibat dari peningkatan kesadaran akan kehadiran luas dan kepentingan ekonomi di kedua negara berkembang dan negara maju. Penelitian ini mendefinisikan kelompok usaha berdasarkan kepemilikan dan hubungan kontrol daan tidak akan mengingkari pentingnya bentuk lain dari hubungan antara perusahaan yang tidak didasarkan pada hubungan kepemilikan (Granovetter 1995) sehingga teori dapat berguna guna kemajuan kewirausahaan di Indonesia. Agar tujuan dapat tercapai usaha kecil menengah harus mampu mengorganisir baik sumber daya manusia, manajemen keuangan dan kemampuan dalam mengendalikan keuangan sehingga perspektif keuangan sangat diperlukan bagi kemajuan usaha kecil menengah di Indonesia.

Hasil penelitian Enrico Guzzini, Donato Iacobucci, Peter Rosa (2012) mengemukakan bahwa perspektif keuangan dan organisasi dapat dipandang sebagai pelengkap dalam menjelaskan kelompok usaha di sektor usaha kecil. Secara khusus, penjelasan keuangan sesuai dengan data dalam memprediksi prevalensi perusahaan padat modal di kelompok usaha sedangkan penjelasan organisasi sesuai dengan data dalam memprediksi adanya pengetahuan perusahaan intensif dalam kelompok-kelompok bisnis. Selain itu, perspektif organisasi tampaknya lebih tepat bila strategi diversifikasi kelompok bisnis yang bersangkutan dan saat menjelaskan struktur kepemilikan perusahaan dikendalikan.

\section{Kunci Langkah-Langkah Strategis dalam Mengatur Bisnis, sebuah Tinjauan Beberapa Fakta Wirausaha Dasar}

Tiga kelompok faktor utama yang mempengaruhi survivabilitas bisnis baru meliputi: (1) karakteristik individu pendiri (2) atribut, karakteristik struktural dan strategi bisnis baru itu sendiri (3) bisnis dan lingkungan ekonomi (Josef et al 1992;. Oliver Falck 2007). Faktor ini berhubungan dengan (1) bagaimana memimpin organisasi, rencana dan memahami lingkungan bisnis yang sangat dinamis, (2) bagaimana mengelola biaya dan rencana struktur 
organisasi internal dan manajemen sumber daya manusia. Pengusaha harus melakukan kegiatan-kegiatan berikut untuk menghindari kegagalan ketika memulai bisnis mereka yaitu meliputi: (1) analisis eksternal dan lingkungan internal (analisis SWOT), (2) analisis persaingan kompetitif (strategi bersaing Porter), (3) menyewa karyawan yang berharga (manajemen sumber daya manusia ), (4) mengontrol arus kas dan kembali mengalokasikan modal investasi untuk mencapai biaya yang efektif (cost management), (5) mempertahankan tim-semangat yang tinggi dan efisiensi operasional (Strategi Struktur Organisasi). Dimana kelima strategi di atas dapat diterapkan untuk meningkatkan survivability dari usaha baru. Analisis SWOT kunci dari lingkungan bisnis dan pengembangan strategi sebagai dasar untuk menilai pilihan strategis di masa depan. SWOT dibagi menjadi 4 pendekatan: Kekuatan (S), Kelemahan (W), Peluang (O) dan Ancaman (T).

Evaluasi faktor internal pengusaha bisa berpikir tentang apa keuntungan dari usahanya dengan perbandingannya pesaing utama ke beberapa pendekatan: pengendalian biaya, ketersediaan sumber daya, struktur organisasi. Contoh: Paten, nama merek yang kuat, reputasi yang baik di antara pelanggan, keuntungan biaya dari kepemilikan, akses eksklusif ke sumber daya alam kelas tinggi, akses yang menguntungkan untuk jaringan distribusi.

Evaluasi kelemahan bahwa pengusaha dapat menyimpulkan kelemahan internal sehingga untuk melaksanakan tindakan tertentu untuk memperbaiki masalah atau setidaknya metode alternatif digunakan untuk mengurangi dampak. Contoh: Kunci dari perlindungan paten, nama merek yang lemah, reputasi buruk di antara pelanggan, struktur biaya tinggi, kurangnya akses ke sumber daya alami terbaik, kurangnya akses ke saluran distribusi kunci.

Evaluasi peluang merupakan faktor eksternal dari lingkungan bisnis untuk mengidentifikasi faktor-faktor yang mendukung pengusahanya. Contoh: Sebuah kebutuhan pelanggan terpenuhi, kedatangan teknologi baru, melonggarkan peraturan dan penghapusan hambatan perdagangan internasional.

Evaluasi Ancaman juga faktor eksternal untuk memprediksi atau memberitahukan faktor yang tidak menguntungkan atau bahkan risiko yang ada atau masa depan yang melawan kelangsungan hidup perusahaan. Contoh: Pergeseran selera konsumen dari produk perusahaan, munculnya produk pengganti, peraturan baru, peningkatan hambatan perdagangan.

Untuk mencapai tujuan yang diinginkan oleh suatu organisasi atau perusahaan maka dibutuhkan langkah-langkah stratregis dalam mengatur bisnis. penerapan strategi justru sangat dibutuhkan guna apa yang diinginkan bersama dapat dicapai dengan sebaik mungkin. Peran strategi ketika diimplementasikan dalam suatu organisasi maka setiap unit atau bagian yang ada dalam organisasi tersebut dapat melaksanakan tugas dan tanggung jawabnya sebaik mungkin. Apalagi melihat perkembangan zaman sekarang ini, dimana setiap organisasi perusahaan telah melakukan ekspansi pasar guna mendapatkan keuntunga yang banyak. Semuanya itu perlu langkah strategis dan taktik yang tepat sehingga proses atau langkah yang diambil oleh pimpinan dapat dijalankan seefektif dan seefisen mungkin.

Persaingan yang memunculkan daya saing erat kaitannya dengan pemahaman mekanisme pasar (standar dan benchmarking), kecepatan dan ketepatan penyampaian produk (barang dan jasa) yang mampu menciptakan nilai tambah. Oleh karena itu, peningkatan daya saing organisasi bersifat unik, tetapi pada intinya dipengaruhi oleh aspek kreativitas, 
kapasitas, teknologi yang digunakan dan jangkauan pemasaran yang dicapai. Hal tersebut diwujudkan dari tampilan produk, produktivitas yang tinggi dan pelayanan yang baik.

Mempekerjakan karyawan yang berharga adalah menyewa karyawan yang berharga, apa yang harus pengusaha lakukan adalah mengikuti Manajemen (HRM) pendekatan Sumber Daya Manusia. Manajemen Sumber Daya Manusia (SDM) adalah fungsi dalam sebuah organisasi yang berfokus pada perekrutan, pengelolaan, dan memberikan arahan untuk orangorang yang bekerja dalam organisasi.

Sumber daya manusia menyediakan sumber untuk keunggulan kompetitif dan kualitas HRM adalah pengaruh yang penting terhadap kinerja perusahaan, itu pendekatan strategis merupakan karakteristik dari HRM. Manajemen personalia dipandang sebagai operasional. Orang yang bekerja untuk sebuah perusahaan adalah salah satu aset utama dan salah satu faktor dalam menentukan kemajuannya. Kualitas pekerja, sikap dan perilaku di tempat kerja, bersama dengan faktor lain, memainkan peran penting dalam menentukan keberhasilan perusahaan.

Hasil penelitian Hashemi, K (2012) mengemukakan bahwa seorang pengusaha harus melakukan kegiatan-kegiatan berikut untuk menghindari kegagalan saat bisnis mereka dimulai: ((1) analisis eksternal dan lingkungan internal (analisis SWOT), (2) analisis persaingan kompetitif (strategi bersaing Porter), (3) menyewa karyawan yang berharga (manajemen sumber daya manusia ), (4) mengontrol arus kas dan kembali mengalokasikan modal investasi untuk mencapai biaya yang efektif (cost management), (5) mempertahankan tim-semangat yang tinggi dan efisiensi operasional (Strategi Struktur Organisasi).

\section{Mempelajari Pengaruh Fungsi Manajemen Sumber Daya Manusia Pada Organisasi Kewirausahaan}

Kegunaan teori dapat memberikan sumbangan yang cukup besar dalam kelayakan usaha dan pertumbuhan usaha karena seiring dengan persaingan yang ketat di jaman sekarang ini mendorong setiap organisasi usaha dan perubahan dalam bidang industri untuk memiliki/memaksa organisasi dan perusahaan menggunakan inovasi dan kewirausahaan untuk mempertahankan daya saing. Jadi apabila perusahaan kreatif serta inovatif dapat menumbuhkembangkan usaha. Dalam hal ini, cara mengaplikasikan dalam aktivitas kewirausahaan yaitu dengan mempersiapkan SDM berkualitas dengan mengoptimalkan kekuatan mental dan eksekutif karyawan untuk memperkuat inovasi dan kreativitas.

Hasil penelitian Hassanpour, A., et al (2012) mengemukakan bahwa ada hubungan yang signifikan antara fungsi sumber daya manusia, pengelolaan sumber daya dan kewirausahaan. Sumber daya manusia dalam organisasi adalah prinsip utama dari organisasi dan keberadaan lingkungan kompetitif, dioptimalkan menggunakan kekuatan mental dan eksekutif karyawan untuk memperkuat inovasi dan kreativitas.

\section{Apa etika bisnis bisa dipelajari dari kewirausahaan}

Dalam perkembangannya etika bisnis tidak lagi menjadi beban yang terpaksa harus dilaksanakan perusahan melainkan sudah menjadi salah satu strategi pengembangan perusahaan dimulai dari perencanaan strategis, organisasi yang baik, sistem prosedur yang transparan didukung oleh budaya perusahaan yang handal serta etika perusahaan yang dilaksanakan secara konsisten dan konsekuen. Tindakan perusahaan berasal dari pilihan dan 
tindakan individu manusia, indivdu-individu ini yang harus dipandang sebagai penjaga utama kewajiban moral dan tanggung jawab moral: individu manusia bertanggung jawab atas apa yang dilakukan perusahaan karena tindakan perusahaan secara keseluruhan mengalir dari pilihan dan perilaku.

Penerapan etika bisnis dalam kewirausahaan mencerminkan keterlibatan perusahaan non nilai-nilai sosial ekonomi yang didorong saat ini, telah sangat diabaikan. Hal ini membuat perusahaan sejalan dengan lebih baik dan membuat mereka pemain kontributif untuk praktek bisnis sehat.

Sebagai contoh, prospek penghasilan lebih mungkin melebih-lebihkan keinginan kebanyakan pengusaha untuk terlibat dalam penebangan, transaksi tidak etis. Hal ini memaksa mereka untuk menipu, berbohong, mencuri dan menyangkal orang lain hak-hak mereka untuk mendapatkan double pendapatan. Sehingga, penerapan etika bisnis sangat penting dalam berwirausaha. Penerapan etika bisnis yang harusnya dijalankan saat ini adalah bertanggung jawab terhadap segala aktivitas perusahaan yang dijalankannya, baik sekarang maupun yang akan datang. Tanggung jawab seorang pengusaha tidak hanya pada segi material, tetapi juga moral kepada berbagai pihak. Komitmen pada berbagai pihak. Mengembangkan dan memelihara hubungan baik dengan berbagai pihak, baik yang berhubungan langsung dengan usaha yang dijalankan maupun tidak. Hubungan baik yang perlu dijalankan, antara lain kepada: para pelanggan, pemerintah, pemasok, serta masyarakat luas. keputusan bisnis yang baik dapat diukur oleh banyak hal dalam bisnis pada kewirausahaan.

Hasil penelitian Hick, Stephen R.C. et al (2009) mengemukakan bahwa dasar nilainilai dan kebajikan pengusaha yaitu orang-orang bertanggung jawab dan produktif menciptakan nilai dan perdagangan dengan orang lain untuk mendapatkan keuntungan. Proses kewirausahaan diawali dengan ide informasi dan kreatif untuk produk atau jasa baru. Pengusaha ambisius dan berani mengambil inisiatif dalam mengembangkan ide menjadi sebuah perusahaan baru. Komitmen pengusaha untuk bertindak, meskipun ketakutan sadar akan risiko, menghubungkan ke kebajikan keberanian.

Pengusaha yang mencapai kesuksesan, termasuk imbalan keuangan dan psikologis untuk menciptakan bisnis yang berkembang, terhubung ke nilai-nilai moral umum berkembang, kebahagiaan, dan pemenuhan. Berkembang, atau kebahagiaan, adalah keadaan hidup sukses.

\section{KESIMPULAN}

Berdasarkan studi literatur di atas dapat disimpulkan bahwa perspektif keuangan dan organisasi pada kelompok usaha kecil dan menengah dapat diterapkan pada aktivitas kewirausahaan. Karena pada zaman ini usaha kecil menengah mendapatkan perhatian khusus dari pemerintah untuk meningkatkan perekonomian di Indonesia, perspektif keuangan dipandang hal yang vital untuk maju tidaknya usaha kecil menengah.

Kunci langkah-langkah strategis dalam mengatur bisnis, sebuah tinjauan beberapa fakta wirausaha dasa dapat diterapkan pada aktivitas kewirausahaan. Karena pada era abad ke 21 ini diperlukan langkah-langkah strategis untuk menganalisis lingkungan, dan mengidentifikasi peluang yang bisa memungkinkan pengusaha dalam mengembangkan dan memanfaatkan keunggulan kompetitif. 
Mempelajari pengaruh fungsi manajemen sumber daya manusia pada organisasi kewirausahaan, dapat disimpulkan bahwa Sumber Daya Manusia (SDM) merupakan sektor sentral dan penting dalam rangka pencapaian tujuan disuatu perusahaan, karena dengan adanya kemampuan skill yang dimiliki SDM/para pekerja serta kualitas SDM dapat menggerakkan perusahaan dengan baik dan benar.

Etika bisnis dapat dipelajari dari kewirausahaan dan dapat diterapkan karena etika bisnis dalam perusahaan memiliki peran yang sangat penting, yaitu untuk membentuk suatu perusahaan yang kokoh dan memiliki daya saing yang tinggi serta mempunyai kemampuan menciptakan nilai yang tinggi, diperlukan suatu landasan yang kokoh.

Sehingga dapat disimpulkan bahwa tanggung jawab seorang pengusaha tidak hanya pada segi material, tetapi juga moral kepada berbagai pihak. Komitmen pada berbagai pihak. Mengembangkan dan memelihara hubungan baik dengan berbagai pihak, baik yang berhubungan langsung dengan usaha yang dijalankan maupun tidak. Hubungan baik yang perlu dijalankan, antara lain kepada: para pelanggan, pemerintah, pemasok, serta masyarakat luas. keputusan bisnis yang baik dapat diukur oleh banyak hal dalam bisnis pada kewirausahaan.

\section{DAFTAR PUSTAKA}

Akbar Hassanpour, Seyyed Mehdi Alvani, Mohammad Alavi. Studying the Effects of the Functions of Human Resource Management on Organizational Entrepreneurship. J Am Sci 2012;8(8):454-464]. (ISSN: 1545-1003). http://www.jofamericanscience.org. 70.

Alberto Bayo-Moriones dan Javier Merino-Díaz de Cerio. 2002. Manajemen Sumber Daya, Strategi dan Operasional Kinerja Manusia di Industri Manufaktur Spanyol, M @ n @ jemen, 5 (3): 175-199.

Ardichvili, A., Cardozo, R. \& Ray, S. 2003. A theory of entrepreneurial opportunity identification and development. Journal of Business Venturing, 18(1), pp.105-123.

Aristoteles. 1984. Nicomachean Ethics. Dalam Karya Lengkap Aristoteles, diedit oleh Jonathan Barnes. 2 jilid. Princeton: Princeton University Press.

Birley, S. \& Westhead, P 1993. A Comparison of New Businesses Established by 'Novice' and 'Habitual' Founders in Great Britain. International Small Business Journal, 12(1), pp.38-60.

Buchanan, James. 2002. "Menyimpan Jiwa Liberalisme Klasik." The Wall Street Journal, 1 Januari.

Fama, E.F. \& Jensen, M.C. 1985. Organizational Forms and Investment Decisions. Journal of Financial Economics, n. 14(1), pp.101-119.

Guzzini, E., Iacobucci, D., Rosa, P. 2012. Financial and organizational perspectives on small and medium-sized business groups. All rights reserved. Short sections of text, not to exceed two paragraphs, may be quoted without explicit permission provided that full credit, including (C) notice, is given to the source. 
Hashemi, K,. 2012. Kunci Langkah Strategis dalam Mengatur Bisnis, sebuah Tinjauan Beberapa Fakta Wirausaha Dasar. Jurnal Amerika Sains; 8 (2) :551-553]. (ISSN: 15451003). ttp://www.americanscience.org. 77.

Hick, Stephen R.C. et al. 2009. What Business Ethics Can Learn Form Entrepreneurship. The Journal of Private Enterprise. Volume XXIV, Number 2.

Hilferding, R. \& Bottomore, T.B. 1981. Finance capital: a study of the latest phase of capitalist development. London; Boston: Routledge \& Kegan Paul.

Iacobucci, D. 2002. Explaining business groups started by habitual entrepreneurs in the Italian manufacturing sector. Entrepreneurship and Regional Development, 14(1), pp.31-48.

Iacobucci, D. \& Rosa, P. 2010. The growth of business groups by habitual entrepreneurs: the role of entrepreneurial teams. Entrepreneurship Theory \& Practice, 34(2), pp.351-377.

Kirzner, Israel. 1973. Persaingan dan Kewirausahaan. Chicago: University of Chicago Press.

Mahesa, AD., Rahardja, E. 2012. Analisis Faktor-Faktor Motivasi Yang Mempengaruhi Minat Berwirausaha. DIPONEGORO JOURNAL OF MANAGEMENT Volume 1, Nomor 1, Tahun 2012, Halaman 130-137 http://ejournal-s1.undip.ac.id/index.php/dbr.

Michael E. Porter. 1980. Strategi Kompetitif, 1 / e, New York: The Free Press.

Nurul, I. N. 2015. Pengaruh Sikap Kewirausahaan, Norma Subyektif, dan Efikasi Diri Terhadap Perilaku Berwirausaha Melalui Intensi Berwirausaha Mahasiswa. Jurnal Ekonomi Pendidikan Dan Kewirausahaan Volume 3, Nomor 1, Tahun 2015 Halaman 5 20 http://ojs.jurnalepk.web.id.

Porter, M.E. 1998. Michael Porter pada Kompetisi. Boston, MA: Harvard Business School Press.

Rand, Ayn. 1964. "The objektivis Etika." Dalam Kebajikan Keegoisan. New York: New American Library.

Rosa, P. \& Scott, M. 1996. Portfolio Entrepreneurs: Some Empirical Evidence on the Multiple Ownership or Control of SMEs, and its Implication for our Understanding of Start-Up and Growth in R. Donckels et al. eds., Research in entrepreneurship and small business: Entrepreneurship and SME research; on its way to the next millenium. Brussels: Aldershot, pp. 113-126. 
